\title{
Impact of haematological characteristic alteration in sago factory effluent treated fish Clasrias batrachus
}

\author{
Ramesh Francis* \\ Department of Biological Sciences and Agriculture, University of Eastern Africa, Baraton, P.O.Box - 2500, Eldoret - \\ 30100, Kenya.
}

Publication history: Received on 14 March 2019; revised on 04 April 2019; accepted on 08 April 2019

Article DOI: https://doi.org/10.30574/gscbps.2019.7.1.0039

\begin{abstract}
In the present study was undertaken to evaluate the Sago effluent toxicity stress symptoms in the fish blood during a long term period. The effect of sago effluent on various Haematological parameters were evaluated exposing the fresh water fish Clarias batrachus to different concentration i.e., (Control, 25\%, 50\% and 75\% Sago effluent concentrations respectively. Changes were observed after 28 days of exposure, (sublethal concentration). Red Blood Cells count (RBC), Haematocrit value (HCT), Mean Corpuscular Volume (MCV) and Mean Corpuscular Haemoglobin (MCH) content decreased when compared to the control. The number of White Blood Cells count (WBC) increased in the effluent treated fishes. Increase and decrease in haematological indices means that fish exposed to effluents were under stress.
\end{abstract}

Keywords: Clarias batrachus; Sago effluent; RBC; WBC; HCT; MCV; MCH

\section{Introduction}

Pollution of aquaculture habitats is an inevitable problem aqua culturist's face. Various pollutants affect survival, growth and reproduction of organisms, particularly those of economic importance [1]. Rapid growth and expansion of industries in recent years has resulted in the substantial increase in effluents which, are normally discharged into open land or aquatic environment causing a number of environmental problems [2,3]. Indiscriminate discharge of these industrial wastes has aggravated the problem of aquatic pollution and contamination thereby causing alterations in the national condition of aquatic medium and consequently results in changes in the internal mechanism as well as morphological imbalance of aquatic organism $[4,5]$

Haematological indices are important parameters to evaluate the general physiological status of fishes and may be considered as stress indicators for estimation of the response reactions of the fish to various environmental conditions [6]. The hematological studies in fishes have assumed greater importance because these parameters were used as an efficient and sensitive index to monitor the physiological and pathological changes induced by natural or anthropogenic factors such as bacterial or fungal infection or pollution of water resources [7]. Blood parameters therefore considered as a useful tool in diagnosing the functional status of the body in response to various stressors [8]. The toxicants are stressors which are accumulated in the fish through the food chain or absorption through the general body surface and severely affect the life supporting system at molecular and biochemical levels. The Pollutants generally produce relatively quick changes in hematological characteristics of fish $[9,10]$. Detrimental changes in blood parameters as a result of contaminants are of great ecotoxicology concern because they have the potential to influence the individual organisms by affecting the susceptibility to disease [11]. Analysis of blood parameters will reveal conditions within the body of the fish long before there is any outward manifestation of disease or effects of unfavorable environmental factors [12].

\footnotetext{
${ }^{*}$ Corresponding author

E-mail address: rameshfrancis2007@gmail.com
} 
In the present investigation an attempt has been made to study the effect of sago factory effluent on haematological responses of the fish Clarias batrachus.

\section{Material and methods}

\subsection{Procurement}

Healthy specimens of Clarias batrachus were procured from Bangalore. Fish of same age and size that hatched from the same lot of eggs (brood stock) were procured. Fish were transported to the laboratory in oxygen filled polythene bag containing water.

\subsection{Acclimatization}

Fish were stocked in a large rectangular cement tank $\left(4^{\prime} \times 3^{\prime} \times 3^{\prime}\right)$ previously soap washed, disinfected with potassium permanganate and thoroughly rinsed thrice prior to filling with water. Fish were acclimatized to the laboratory condition for 15 days before being used for experiments.

\subsection{Diet and feeding}

During the holding period, stocks were fed ad libitum once daily with goat liver pieces. Feeding was given at least one hour prior to replacement of tank water. Feeding was withheld 24 hours prior to the commencement of all experiments.

\subsection{Maintenance}

During acclimatization, the stock was maintained at natural photoperiod (LD=12:12) and ambient temperature $(25 \pm 1$ $\left.{ }^{\circ} \mathrm{C}\right)$. Water was replaced every 24 hours and well aerated in order to ensure sufficient oxygen supply to fish.

\subsection{Recruitment of fish for experiments}

After acclimatization, fish weighing $4 \mathrm{~g}$ to $7 \mathrm{~g}$ were selected for experiments and transferred into clean plastic water trough of 20 liters capacity.

\subsection{Collection}

The treated and untreated Sago industry effluents were collected from a private Sago industry, situated at Poonachi near Ammapet of Erode District, Tamil Nadu. The effluent from the industry was collected and transported to the laboratory and used for further experiments.

\subsection{Experimental setup}

The concentrations chosen were $25 \%, 50 \%$ and $75 \%$ of treated sago effluent. The experiments were conducted in plastic trough capacity of 20 liters. For each experiment 10 individuals were reared in respective troughs and controls were maintained in effluent free medium. The fishes were utilized for the experimental studies only after the acclimatization for a minimum period of 15 days. These experimental sets were maintained for 28 days by changing the same quantity of effluent to the respective sets.

\subsection{Haematological study}

The blood from the caudal vein of control and treated fish was collected for haematological investigation. RBC, WBC, HCT, MCV and MCH were examined following the standard procedures.

\section{Results}

Haematological parameters such as RBC count, WBC count, Haematocrit (HCT), Mean Corpuscular Value (MCV) and Mean Corpuscular Haemoglobin (MCH) were predicted by utilizing the blood sample of control and effluent exposed fishes.

The RBC count registered in control, $25 \%, 50 \%$ and $75 \%$ concentrations were $0.26 \times 10^{6} / \mathrm{mm}^{3}, 0.24 \times 10^{6} / \mathrm{mm}^{3}$, $0.29 \times 10^{6} / \mathrm{mm}^{3}$ and $0.79 \times 10^{6} / \mathrm{mm}^{3}$ respectively. The RBC count was slightly decreased in $25 \%$ and then increased with increasing of concentrations $50 \%$ and $75 \%$ when compared to control. 
The WBC count recorded in control was $10.3 \times 10^{3} / \mathrm{mm}^{3}$, whereas in $25 \%$ conc. $9.3 \times 10^{3} / \mathrm{mm}^{3}$, in $50 \%$ conc. $12.2 \times 10^{3} / \mathrm{mm}^{3}$ and in $75 \%$ conc. $8.4 \times 10^{4} / \mathrm{mm}^{3}$. The results of WBC count showed differential response. Maximum numbers of WBC are seen in 50\% effluent concentration treated individuals.

The Haematocrit value was found to be decreased in 25\% from control and it was increased in 50\% and $75 \%$ concentrations. The values recorded were $2.9 \%, 2.6 \%, 3.0 \%$ and $8.8 \%$ for control, $25 \%, 50 \%$ and $75 \%$ concentrations of sago effluent respectively.

The mean corpuscular value showed slight decreased in all three concentrations when compared to the control. The mean corpuscular value of control group showed the value of $111.8 \mu \mathrm{m} 3$ whereas in the test concentration of $25 \%$, $50 \%$ and $75 \%$ were $106.8 \mu \mathrm{m}^{3}, 104.1 \mu \mathrm{m}^{3}$ and $110.4 \mu \mathrm{m}^{3}$ respectively.

The control group, the corpuscular haemoglobin level was recorded to be $37.1 \mathrm{pg}$. In the test concentrations of $25 \%$, $50 \%$, and $75 \%$ were observed to be $39.0 \mathrm{pg}$, $40.0 \mathrm{pg}$ and $29.9 \mathrm{pg}$ respectively.

The results of the effect of sago effluent on haematological parameters of Clarias batrachus is presented in Table 1.

Table 1 Haematological parameters of Clarias batrachus treated in control and different concentrations of treated sago effluent

\begin{tabular}{|c|c|c|c|c|c|}
\hline $\begin{array}{l}\text { Sr. } \\
\text { No. }\end{array}$ & Parameters & Control & $\begin{array}{l}25 \% \\
\text { Concentration }\end{array}$ & $\begin{array}{l}50 \% \\
\text { Concentration }\end{array}$ & $\begin{array}{l}75 \% \\
\text { Concentration }\end{array}$ \\
\hline 1. & $\begin{array}{l}\text { RBC Count } \\
\text { (Cells } / \mathrm{mm} 3 \text { ) }\end{array}$ & $0.26 \times 106$ & $0.24 \times 106$ & $0.29 \times 106$ & $0.79 \times 106$ \\
\hline 2. & $\begin{array}{l}\text { WBC Count } \\
\text { (Cells } / \mathrm{mm} 3)\end{array}$ & $10.3 \times 103 / \mathrm{mm} 3$ & $9.3 \times 103$ & $12.2 \times 103$ & $8.4 \times 103$ \\
\hline 3. & Haematocrit (HCT) \% & 2.9 & 2.6 & 3.0 & 8.8 \\
\hline 4. & $\begin{array}{l}\text { Mean Corpuscular Value } \\
(\mathrm{MCV})(\mu \mathrm{m})\end{array}$ & 111.8 & 106.8 & 104.1 & 110.4 \\
\hline 5. & $\begin{array}{l}\text { Mean Corpuscular } \\
\text { Haemoglobin }(\mathrm{MCH})(\mathrm{pg})\end{array}$ & 37.1 & 39.0 & 40.0 & 29.9 \\
\hline
\end{tabular}

\section{Discussion}

In the present investigation haematological parameters such as RBC count, WBC count, HCT (Haematocrit) value, MCV (Mean Corpuscular Value) and MCH (Mean Corpuscular Haemoglobin) were studied in the fish treated in sub lethal concentration of treated sago effluent.

In the present study the exposure of Clarias batrachus sago effluent caused a concentration dependent reduction in the values of red blood cell (RBC), packed cell volume (HCT), mean corpuscular haemoglobin (MCH), and mean corpuscular volume (MCV). Similar observations were made by Parveen et al. [13] in the fish exposed to different concentrations of tannery effluent. Akinrotimi, et al. [14] observed the exposure of T. guineensis to sublethal levels of industrial effluents which is obtained in the environment, results in concentration dependent decreases in, RBC, PCV, MCH. The reduction in RBC and PCV consequently led to reduction in oxygen carrying capacity of blood, resulting to anaemic condition in the fish. Similar observations were registered by Ramesh and Saravana [15] Cyprinus carpio exposed to chlorpyrifos.

Ates et al. [16] also found the reduction in erythrocyte, haemoglobin and hematocrit values in fish Onchorynchus mykiss exposed to lead and copper which can be an indicator of anemia with the subsequent result of inhibition of erythropoietin in the haemopoietic organism.

In the present investigation value of white blood cell count (WBC) has increased slightly in different concentrations of the effluent when compared to the control medium. Similar observations were made Mishra and Poddar [17] who observed a significant augmentation in WBC was observed upon exposure to higher concentrations of Phenol and effluent. Overall, percent changes in WBC in response to higher of the toxicants were found to be far higher than control. Shaheen [18] has also observed the increase in leucocytes count in C. punctatus exposed to chromium and copper, and 
in Cyprinus carpio exposed to hexavalent chromium. Leucocytes increased following copper exposure and were significantly higher in Prochilodous scrofa fish exposed to increased copper concentration [19]. Similar trends were reported in the fish exposed to various pollutants in $C$. punctatus exposed to zinc).

\section{Conclusion}

Haematological characteristics are an important tool that can be used to understand as an effective and sensitive index to monitor physiological and pathological changes in fishes. In the present study the fish exposed to Sago effluent showed decrease in RBC, HCT, MCV and MCH levels, whereas there was an increase in WBC count with increasing the concentrations of the effluent. Changes in haematological parameters depend on the aquatic biotope, fish species, age, and sexual maturity and health status. Haematological parameter are highly useful as the early warning for the process of xenobiotic and their effects, which make it possible to implement corrective measures before aquatic organisms and their communities suffer irreversible damage.

\section{Compliance with ethical standards}

\section{Acknowledgments}

The author (Ramesh Francis) is very thankful to his family and research supervisor Dr. K Nagarajan. Because without their cooperation this review was not possible.

\section{Disclosure of conflict of interest}

None

\section{References}

[1] Louredes MA, Aralar C and Emiliano V A. (1993). Effect of long-term exposure to a mixture of cadmium, zinc and inorganic mercury on two strains of Tilapia Oreochromis niloticus (L). Bulletin of Environmental Contamination and Toxicology, 50, 891-897.

[2] Ramona A, Biswas AK, Kundu S, Saha JK and Yadav RBR. (2001). Efficacy of distillery effluent on seed germination and seedling growth in mustard cauliflower and radish. Proceedings of the National Academy of Sciences, India, 71(b11), 129 -135.

[3] Chezhien A, Kabilan, Suresh Kumar T, Senthanol-Selvan D and Sivakumari K. (2010). Impact of common mixed effluent of Sipcot industrial estate on histopathological and biochemical changes in estuaries fish Lates calcrifer. Current Research Journal of Biological Sciences, 2(3), 201-209

[4] Yadav A, Neraliy S and Singh R. (2005). Effect of fertilizer industrial effluent in the behaviour and morphology of fresh water cat fish. Heteropenenstes fossils (Bloch). Department of Zoology, University of Aloghbord, India.

[5] Gabriel UU, Ezeri GNO, Ikeme PM and Ikwul EF. (2006). Haematoxicity of proxure to juvenile Clarias gariepinus (Burchell, 1822) under laboratory conditions. Pollution Research, 25(2), 1-6.

[6] Docan A, Cristea V, Grecu I and Dediu L. (2010). Haematological response of the European catfish, Silurus glanis reared at different densities in "flow-through" production system. Archiva Zootechnica, 13(2), 63-70.

[7] Blaxhall PC. (1972). The haematological assessment of the health of fresh water fish. A review of selected literature. Journal of Fish Biology, 4, 593-604.

[8] Chekrabarthy P, Benerjee V. (1988). Effects of sublethal toxicity of three organophosphorus pesticides on the peripheral haemogram of the fish, (Channa punctatus). Environment and Ecology, 6, 151-158.

[9] Johansen JA, Kennedy CJ, Sureeting M, Farrell AP and ckeown BA. (1994). Sublethal effects of tetrachloroguaiacol on juvenile rainbow trout, Oncorhynchus mykiss, following acute and chronic exposure. Can. J. Fisheries and Aquatic Sciences, 51, 1967-1974.

[10] Rizkalla EH, Abd El -Haleem ME and Shalaby AME. (1999). Haematological changes in Cyprinus carpio L. as a result of short and long term exposure to different combinations of copper, cadmium and zinc. Egyptian Journal of Aquatic Biology and Fisheris, 175-193. 
[11] Suvetha L Ramesh M and Saravana M. (2010.) Influence of cypermethrin toxicity on ionic regulation and gill $\mathrm{Na}+\mathrm{K}+$ - ATPase activity of a freshwater teleost fish Cyprinus carpio. Environmental Toxicology and Pharmacology, 29, 44-49.

[12] Musa SO and Omoregie E. (1999). Haematological changes in the mud fish Clarias gariepinus exposed to malachite green. Journal of Aquatic Sciences, 14, 37-42.

[13] Parveen S, Singh D, Ram Bharose, Rout S, Khan MA and Ansari EF. (2017). Tannery effluent effect on the haematological parameters of freshwater fish, Channa punctatus. Journal of Applied and Natural Science 9(1), $201-205$.

[14] Akinrotimi OA, Orlu EE and Gabriel UU. (2013). Haematological Responses of Tilapia guineensis Treated with Industrial Effluents. Applied Ecology and Environmental Sciences, 2013, 1(1), 10-13.

[15] Ramesh M and Saravana M. (2010). Haematological and biochemical responses in a fresh water fish. Cyprinus carpio exposed to chlorpyrifos. International Journal of Integrative Biology, 3(1), 80-83.

[16] Ates B, Orun I, Talas ZS, Durmaz G and Yilmaz I. (2008). Effects of sodium selenite on some biochemical and hematological parameters of rainbow trout (Oncorhynchus mykiss Walbaum, 1792) exposed to $\mathrm{Pb} 2+$ and $\mathrm{Cu} 2+$. Fish Physiology and Biochemistry, 34, 53-59.

[17] Mishra A and Poddar A Niyogi (2013). Haematology of freshwater Murrel (Channa punctatus Bloch), exposed to Phenolic industrial wastes of the Bhilai Steel plant (Chhattisgarh, India). International Journal of Scientific \& Engineering Research, 4(4), 1866- 1883.

[18] Shaheen T. (2009). Studies on chromium toxicity in Cyprinus carpio brood stock progeny relationship. Ph.D Thesis, University of Punjab, Lahore, Pakistan.

[19] Mazon AF, Cerqueira C and Fernandes MN. (2002). Gill cellular changes induced by copper exposure in the South American tropical fresh water fish Prochilodous scrofa. Environmental Research, 88, 52-63.

\section{How to cite this article}

Ramesh F. (2019). Impact of haematological characteristic alteration in sago factory effluent treated fish Clasrias batrachus. GSC Biological and Pharmaceutical Sciences, 7(1), 86-90. 